\title{
ASSESSING THE CARBON FOOTPRINT OF A DEDICATED ALL-CARGO AIRLINE: THE CASE OF CARGOLUX INTERNATIONAL AIRLINES
}

\author{
Glenn S. Baxter ${ }^{1 *}$ \\ ${ }^{1}$ School of Tourism and Hospitality Management, Suan Dusit University, Huahin Prachaup Khiri Khan, Thailand, \\ 77110
}

Received 14 September 2020; received in revised form 16 November 2020; accepted 18 December 2020

\begin{abstract}
The objective of this study was to examine Cargolux International Airlines, one of the world's largest dedicated all-cargo airlines, carbon footprint and to identify how it has been influenced by its route network expansion and the operation of the nextgeneration, Boeing B747-8 freighter aircraft. The study covered the period 2005 to 2018. To achieve the objectives of the study, an in-depth qualitative longitudinal case study research approach was used. The data that was sourced for the study was examined using document analysis. The study found that Cargolux International Airlines annual carbon dioxide $\left(\mathrm{CO}_{2}\right)$ emissions increased from 2,845,000 tonnes in 2005 to 4,093, 521 tonnes in 2018. The increase in the airline's annual carbon dioxide $\left(\mathrm{CO}_{2}\right)$ emissions is due to a higher level of services, route network expansion, and an increase its fleet of freighter aircraft. Over the study period, Cargolux's annual carbon dioxide emissions $\left(\mathrm{CO}_{2}\right)$ per available tonne kilometer (ATK) exhibited a downward trend, decreasing from a high of 386.5 grams per available tonne kilometre (ATK) in 2006 to a low of 330.8 grams per available tonne kilometer (ATK) in 2018. A similar trend occurred with the airline's annual carbon dioxide emissions $\left(\mathrm{CO}_{2}\right)$ per freight tonne kilometer (FTK), which decreased from a high of 540 grams per freight tonne kilometer (FTK) in 2011 to a low of 330.8 grams per available freight tonne kilometer (FTK) in 2017. These trends were very favorable given the expansion in services and in enplaned air cargo tonnages throughout the study period. The case study revealed that the airline's fleet rollover plan, in which Cargolux acquired a fleet of 14 state-of-the art Boeing B747-8 freighters, has resulted in the most substantial reductions in carbon dioxide $\left(\mathrm{CO}_{2}\right)$ emissions. The more favorable fuel efficiency of this aircraft results in lower carbon dioxide $\left(\mathrm{CO}_{2}\right)$ emissions for their operators. In addition to operating a modern fuel-efficient fleet, Cargolux has implemented a very broad range of measures and initiatives that are designed to mitigate its carbon footprint from both its flight and ground operations.
\end{abstract}

Keywords: Aircraft emissions, all-cargo airlines, carbon footprint, carbon dioxide emissions, case study, Cargolux International Airlines.

(C) 2020 Journal of Urban and Environmental Engineering (JUEE). All rights reserved.

\footnotetext{
*Correspondence to: Glenn Baxter. E-mail: g glennbax@dusit.ac.th
} 


\section{INTRODUCTION}

The air transportation of goods/freight for commercial purposes plays a highly substantial role in the world economy. The world air cargo industry has grown rapidly in recent decades and is now an integral part of the global economy. The world's airlines transport around 35 per cent of the annual global trade by value (International Air Transport Association, 2020). In the global air cargo industry, air cargo capacity is provided by combination passenger airlines. These are airlines that carry passengers on the main deck and air cargo in their passenger aircraft lower lobe belly-holds. Some combination airlines, for example, Cathay Pacific Airways, Korean Air, and Singapore Airlines also operate freighter services in addition to their passenger services. Air cargo capacity is also provided by dedicated all-cargo carriers as well as the integrators, for example, DHL Express, FEDEX and United Parcel Service (UPS) (Baxter \& Bardell, 2017). All-cargo services are operated by dedicated freighter aircraft with all the available capacity dedicated to air cargo transportation (Cook \& Billig, 2017; Dresner \& Zou, 2017; Tretheway \& Andriulaitis, 2016). According to Boeing Commercial Airplanes (2018), around 56\% of global air cargo revenue ton kilometres (RTKs) is currently carried in dedicated freighter aircraft. A freighter aircraft is an aircraft that has been expressly designed for the carriage of air cargo or one which has been converted from a passenger configuration to a freighter aircraft and is subsequently used to transport air cargo, express, and so forth, rather than passengers (Wensveen, 2016).

All around the world, the environmental sustainability of air transport has receiving greater focus in recent times due to its critical impact on climate change and on the environment (Budd, 2017; Chen, 2012; Teoh \& Koo, 2016). Indeed, in recent times, many airlines around the world have recognized the importance of environmental protection (Niu et al., 2016), and considering this many airlines have taken strong environmental positions (Roza, 2009). Airlines have become increasingly committed to becoming more "green," or environmentally friendly (Abdullah et al., 2016; Hagmann et al., 2015; Migdadi, 2020; Zhou \& Zhang, 2020). The key challenges confronted by policy makers and air transportation industry stakeholders is their ability to reduce aviation greenhouse gas emissions while at the same time sustaining mobility timesensitive cargo (and passengers) as well as satisfying future demand for air transportation in both developing and emerging countries (Sgouridis et al., 2011). At a global level, the peak global airline industry body - the International Air Transport Association (IATA) - has recognized the requirement to address the global challenge of climate change and has subsequently adopted a set of ambitious targets to mitigate carbon dioxide $\left(\mathrm{CO}_{2}\right)$ emissions from air transport operations. The association has targeted an average improvement in aircraft fuel efficiency of $1.5 \%$ per year from 2009 to 2020 , a cap on net aviation carbon dioxide $\left(\mathrm{CO}_{2}\right)$ emissions from 2020, and a reduction in net aviation carbon dioxide $\left(\mathrm{CO}_{2}\right)$ emissions of $50 \%$ by 2050 , relative to 2005 levels (International Air Transport Association, 2018). In 2018, dedicated freighter operations accounted for around $8 \%$ of the total global airline carbon dioxide $\left(\mathrm{CO}_{2}\right)$ emissions (Graver et al., 2019).

Despite their acknowledged role in facilitating the movement of global commerce, there has been, to the best of the author's knowledge, no previously reported study that has examined the carbon footprint of a major global all-cargo carrier and the strategies employed by that airline to mitigate its environmental impact from its carbon dioxide $\left(\mathrm{CO}_{2}\right)$ emissions. The objective of this paper is to address this apparent gap in the literature. According to Wiedemann and Minx (2007, p. 5), "the carbon footprint is a measure of the exclusive total amount of carbon dioxide emissions that is directly and indirectly caused by an activity or is accumulated over the life stages of a product".

Based on its international standing and commitment to environmentally sustainable operations, Cargolux International Airlines (hereafter Cargolux) was selected as the case firm for this study. The objective of this study is to examine the airline's carbon footprint and to identify how it has been influenced by its route network expansion and the operation of the next-generation, Boeing B747-8 freighter aircraft. A secondary objective is to examine the annual trends in the airline's carbon dioxide $\left(\mathrm{CO}_{2}\right)$ emissions arising from the use of ground service equipment (GSE) and to identify how these have changed over the study period. A final objective is to examine the various strategies that have been implemented by Cargolux to reduce its carbon footprint. The study covered the period 2005 to 2018 .

The remainder of the paper is organized as follows: the literature review that sets the context of the case study is presented in Section 2. The research method that underpinned the study is presented in Section 3. The Cargolux case study is presented in Section 4. Section 5 presents the key findings of the study.

\section{BACKGROUND}

\section{Aircraft and ground-based service equipment emissions}

The growth of commercial air transport has driven concerns over air quality (Daley, 2016; Harrison et al., 
2015). By consuming fuel, aircraft produce emissions of carbon dioxide $\left(\mathrm{CO}_{2}\right)$, nitrogen oxides $\left(\mathrm{NO}_{\mathrm{x}}\right)$, particles (principally soot) of sulphur oxides $\left(\mathrm{SO}_{\mathrm{x}}\right)$, carbon monoxide (CO), as well as various hydrocarbons. First, and generating the largest percentage share, are the emissions of carbon dioxide $\left(\mathrm{CO}_{2}\right)$ which are produced in direct proportion to the volume of jet fuel used to operate flights over any distance (Sales, 2016). Water vapor is also formed from the burning of jet fuels. at altitude, condensation trails from the aircraft. these comprise frozen ice crystals which deflect a small amount of sunlight away from the earth's surface and reflect more infrared radiation back toward earth. this produces an overall warming effect on the earth's atmosphere (Sales, 2013). After water vapor, carbon dioxide $\left(\mathrm{CO}_{2}\right)$ is regarded as the second most important of all the greenhouse gases (Drewer et al., 2018; Ngo \& Natowitz, 2016). Furthermore, aircraft often travel considerable distances at a variety of altitudes, generating emissions that may potentially have an impact on air quality in not only local, but also regional and global environments (International Civil Aviation Organization, 2011).

Ground support equipment (GSE) refers to the specialized vehicles and equipment that provide service to an aircraft whilst it is parked at the gate or on the ramp (Hazel et al., 2011). Ground support equipment (GSE), for example, aircraft push-back tugs, aircraft loaders, catering trucks and the tugs that haul passenger baggage and air cargo within the airport precinct, which are typically powered by diesel or petrol engines, also produce exhaust emissions. thus, gaseous emissions of carbon dioxide $\left(\mathrm{CO}_{2}\right)$, as well as carbon monoxide $(\mathrm{CO})$ and nitrous oxide $\left(\mathrm{NO}_{\mathrm{x}}\right)$ and particulates $(\mathrm{PMs})$ from aircraft, ground access transport, such as buses and taxis, power generation and on-airport ground transport vehicles, all negatively impact local air quality (Budd, 2017).

\section{Carbon offsetting and reduction scheme for international aviation (CORSIA)}

In October 2016, the member states of the International Civil Aviation Organization (ICAO) reached a historic decision to adopt a world-wide market-based measure for aviation emissions (Attanasio, 2018). In 2021, an increasing share of the carbon emission growth in international air transport will be subject to offsetting under the ICAO "Carbon Offsetting and Reduction Scheme for International Aviation" (CORSIA) program (Maertens et al., 2019). CORSIA is a worldwide based market-based measure that has been designed to offset international aviation carbon dioxide $\left(\mathrm{CO}_{2}\right)$ emissions to stabilize the levels of such emissions from 2020 onwards. The offsetting of carbon dioxide $\left(\mathrm{CO}_{2}\right)$ emissions in the air transport industry will be achieved through the acquisition and cancelation of emissions units from the global carbon market by aircraft operators (International Civil Aviation Organization, 2020b). The CORSIA program will be rolled out in three phases with the pilot phase operating from 20212023. The first phase will be from 2024 to 2026. Both the pilot and first phases are voluntary. The second phase of the program is targeted at the 2027 to 2035 time-period (Javed et al., 2019). Following the pilot and first phase, a second mandatory scheme will enter in effect for all ICAO member states, except for some least developed countries (Scott \& Trimarchi, 2020).

\section{The greenhouse gas protocol}

The greenhouse gas protocol has established a comprehensive global standardized framework to measure and manage greenhouse gas (GHG) emissions from both the private and public sectors, through value chains, and mitigation actions (Greenhouse Gas Protocol, 2020). The greenhouse gas protocol categorizes greenhouse gases into both direct and indirect emissions and further categorizes them into Scope 1, Scope 2, and Scope 3 emissions (Jones, 2009). Scope 1, direct emissions, includes those emissions from sources that are owned or controlled by the firm (Girella, 2018; Vásquez et al., 2015). Scope 2, indirect emissions, come from the purchase of electricity, heat, steam or cooling. Scope 3 emissions are all the other indirect emissions that arise from the consequences of the various activities undertaken by a firm but occur from sources that are not owned nor controlled by that firm (Mazhar et al., 2019). Although there are variations in air quality regulations by country (Budd, 2017), airlines are now increasingly recording and reporting emissions in terms of Scope 1, Scope 2 or Scope 3 emissions.

\section{The use of sustainable aviation fuels}

In recent times, there has been a growing trend by airlines to use aviation biofuel as an environment sustainability measure (Baxter et al., 2020). Sustainable aviation fuel (SAF) refers to a blended end product that comprises conventional Jet A-1 and aviation biofuel which conforms to applicable to the ASTM Standard specification D1655 or DEFSTAN 91-91 specifications for use in jet aircraft (Bardell \& Ashton, 2018). For many years now, airlines have experimented with biofuels. The objective has been to reduce their carbon emissions (Gegg et al., 2014; Schäfer, 2016). Aviation biofuels are therefore becoming an important substitute for fossil fuel in the airline industry as they offer several 
advantages, including sustainability, they are environmentally friendly, and they offer good adaptability ( $\mathrm{Su}$ et al., 2015). In addition, the replacement of fossil fuels by aviation biofuels is one of the primary strategies to decrease carbon dioxide $\left(\mathrm{CO}_{2}\right)$ emissions by $50 \%$ by 2050 (Bauen \& Nattrass, 2018; Dodd et al., 2018).

\section{RESEARCH METHODOLOGY}

\section{Research approach}

This study used a qualitative longitudinal research design (Derrington, 2019; Hassett \& PaavilainenMäntymäki, 2013; Neale, 2019). The purpose of longitudinal research is to collect and analyse qualitative data on growth, change, and development over time. The principal advantage of a qualitative longitudinal research design is that it reveals change and growth in an outcome over time (Kalaian \& Kasim, 2008).

\section{Data collection}

The data used in the study was obtained from a range of documents, company materials available on the internet and records as sources of case evidence. Documents included the Cargolux International Airlines Annual Reports, Cargolux International Airlines Annual Sustainability Reports, and the airline's websites. A comprehensive search of the leading air cargo and air transport journals and magazines was also conducted in the study. A search of the SCOPUS and Google Scholar databases was also performed in the study.

The key words used in the database searches included "Cargolux environmental policy", "Cargolux environmental carbon dioxide emissions from aircraft operations", "Cargolux environmental carbon dioxide emissions arising from ground service equipment, "Cargolux Scope 1 carbon dioxide emissions" "Cargolux Scope 2 carbon dioxide emissions". "Cargolux membership of CORSIA", "Cargolux's use of sustainable aviation biofuels", and "Cargolux carbon footprint reduction initiatives".

The study therefore used secondary data. The three principles of data collection as recommended by Yin (2018) were followed: the use of multiple sources of case evidence, creation of a database on the subject and the establishment of a chain of evidence.

\section{Data analysis}

The empirical data collected for the case studies was examined using document analysis. Document analysis is a research technique that is quite commonly used in case studies. Document analysis focuses on the information and data from formal documents and company records that are gathered by a researcher when conducting their study (Andrew et al., 2011; Yin, 2018). Following the guidance of Scott (2014), the documents collected for the study were examined according to four criteria: authenticity, credibility, representativeness and meaning.

The document analysis was conducted in six discrete stages. The first phase involved planning the types and required documentation and ascertaining their availability. The second phase involved gathering the documents and developing and implementing a scheme for the document management. Following the conclusion of Phase 2, the documents were reviewed to assess their authenticity, credibility and to identify any potential bias. In Phase 4, the content of the collected documents was interrogated, and the key themes and issues were identified. Phase 5 involved reflection and refinement to identify any difficulties associated with the documents, reviewing sources, as well as exploring the documents content. The analysis of the data was completed in Phase 6 of the document analysis process (O'Leary, 2004).

The documents gathered for the study were downloaded and stored in a case study database (Yin, 2018). The documents were all in English. Each document was carefully read, and key themes were coded and recorded (Baxter, 2019).

\section{RESULTS}

\section{A brief overview of Cargolux International Airlines}

Cargolux was established in March 1970 to operate world-wide air cargo charters from its home base located at Luxembourg's Findel Airport (Green \& Swanborough, 1975). The airline's shareholders were Luxembourg's national airline Luxair, Swedish shipping line Salen Shipping Group, Icelandic airline Loftleider Icelandic and private interests (Buyck, 2004). Each shareholder held a third of the shares with the remainder being held by private interests (Belson, 1977). Cargolux started operations in May 1977 (Flight International, 1979) with a single Canadair CL-44D4 aircraft (Belson, 1977; Nelms, 1996).

In 1973, Cargolux took delivery of its first jetpowered aircraft, a McDonnell Douglas DC8-61F. In 1979, the airline added its first Boeing 747-200F freighter aircraft. The airline also added two Boeing B707-331 "combi aircraft" to its fleet in 1979. In 1985, Cargolux withdrew its fleet of McDonnell Douglas DC8F and Boeing 707' aircraft, and in the process became Europe's first all Boeing 747-200F air cargo operator (Nelms, 1996). 
In 1993, Cargolux took delivery of its first Boeing B747-400 freighter aircraft. This aircraft model provided Cargolux with a better range capability and increased air cargo capacity (Nelms, 1996). Cargolux was the first all-cargo airline to take delivery of the Boeing B747-400 freighter aircraft. Initially, it was envisaged that the Boeing B747-400F would rationalize the Cargolux fleet. This rationalization would be achieved through operating its fleet of Boeing B747-200 freighter aircraft on shorter routes and the Boeing 747400 freighter aircraft on longer air routes. However, costs savings arising from the operation of a two-crew cockpit, $18 \%$ fuel savings, lower maintenance costs, and greater capacity of the Boeing B747-400 led to the decision to replace the Boeing 747-200 fleet with the Boeing B747-400 freighter aircraft (Air Transport World, 1998).

Cargolux together with Japan-based Nippon Cargo Airlines (NCA) were the launch customers for the Boeing 747-8 freighter aircraft (Ostrower, 2011). Following the orders for 13 Boeing 747-8 freighters by Cargolux and 14 by Nippon Cargo Airlines, Boeing officially launched the $747-8 \mathrm{~F}$ program (Conway, 2012). Cargolux took delivery of its first Boeing 747-8 aircraft on October 12, 2011 (Boeing Commercial Airplanes, 2011). At the time of the present study, Cargolux operated a fleet of 14 Boeing 747-8 freighters, 11 Boeing 747-400 and 5 Boeing 747-400ERF freighter aircraft (Cargolux International Airlines, 2020c). The airline's worldwide route network covers 90 destinations. In addition to its scheduled flights, Cargolux also operates full and part-charter services (Cargolux International Airlines, 2020b).

Cargolux entered a joint venture with Italian-based interests in December 2008 to establish Cargolux Italia S.p.A. The airline operates a fleet of four Boeing B747400 freighter aircraft (Cargolux Italia, 2020).

Figure 1 presents Cargolux's annual enplaned air cargo tonnage and freight tonne kilometres performed (FTKS) for the period 2005 to 2018. According to Daley (2016, p. 36), a freight tonne kilometre (FTK) is defined "as the mass of air cargo multiplied by the distance that the cargo is carried". Cargolux's annual enplaned air cargo tonnage and FTKs grew from 644,613 tonnes and 5.2 billion FTKs in 2005 to 1,053,626 tonnes and 8.4 billion FTKs in 2018, respectively, as illustrated in Figure 1. As can be observed in Figure 1, both the annual enplaned tonnage and FTKs declined in 2009. This decrease can be attributed to the lower daily utilization of the airline's freighter fleet and the sale of two freighter aircraft to United Parcel Service (UPS) in September 2009 (Cargolux Airlines International, 2010). Figure 1 also shows that there was a further decline in Cargolux's annual enplaned tonnage and FTKs in 2012,which may be attributed to the downturn in world trade and the goods that were traded moved towards bulk commodities which were more suitable for ocean transport during 2012 (International Air Transport Association, 2013). From 2012 to 2018, the airline has recorded growth in both their annual enplaned air cargo tonnage and FTKs performed reflecting the patronage of the airline (Fig. 1).

\section{Cargolux International Airlines environmental policy and related initiatives}

Historically, Cargolux has taken responsibility for its impact on climate change and the role that commercial air transport plays. Accordingly, the airline has a policy of operating a fleet of the most environmentally friendly and energy efficient freighter aircraft. The company has also sought to mitigate its environmental impact at its office and facilities through such measures as energy savings and the strengthening of environmental awareness amongst its workforce. Cargolux has adopted near and long-term goals that are in accordance with the International Air Transport Association (IATA) targets for airlines to reduce carbon dioxide $\left(\mathrm{CO}_{2}\right)$ emissions with the ultimate objective of achieving carbon neutral growth (Cargolux Airlines International, 2017a).

A key element of Cargolux's environmental policy is that the airline aims to reduce its environmental footprint and prevent pollution. Accordingly, Cargolux has implemented an Environmental Management System (EMS) that establishes and monitors key environmental performance indicators. These data are made available through the company's Sustainability Reports and through dialogue with key stakeholders (Cargolux International Airlines, 2020a). Cargolux's environmental management system (EMS) is in accordance with the requirements of the ISO 14001 certification in defining how a firm should approach environmental challenges (Cargolux International

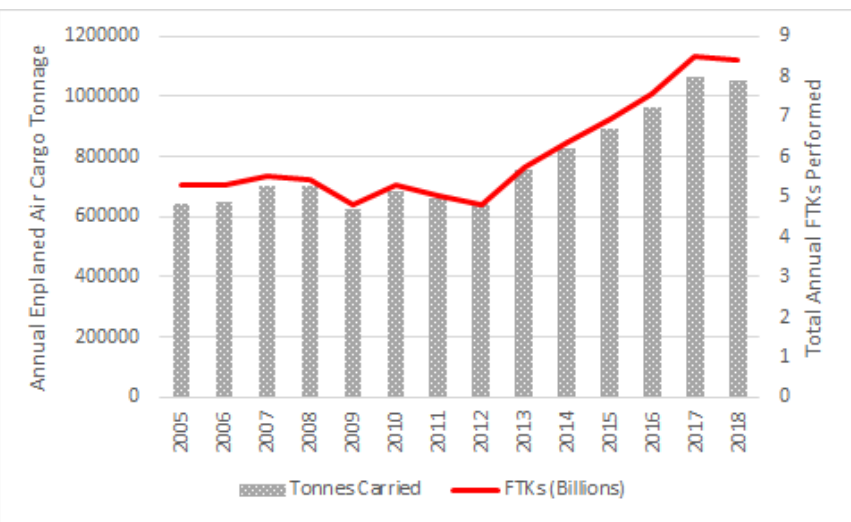

Fig. 1 Cargolux International Airlines annual enplaned air cargo tonnage and freight tonne kilometres (FTKs): 2005-2018 Source: Cargolux International Airlines (2009, 2012, 2016, 2019). 
Airlines, 2015). At the time of the present study, Cargolux's Environmental Management System (EMS) was ISO 14001:2015 compliant for the period 03 May 2018 to 18 March 2021 (Cargolux International Airlines, 2018a).

Furthermore, the company's senior management have a key role to play by ensuring that financial, human, and technical resources are provided so that the company can achieve its environmental objectives. Furthermore, Cargolux is fully compliant with all relevant environmental laws and regulations (Cargolux International Airlines, 2020a).

On 20 October 2006, Cargolux, as one Luxembourg's major firms, signed a "Charter on Corporate Social Responsibility and Sustainable Development agreement". The Charter incorporates an important element of modern management by which large firms and corporations not only have a responsibility to the many stakeholders that are affected by the firm's activities, including its employees, customers, the local community, and the environment. With this Charter, Cargolux acknowledged its responsibilities and the company stressed its commitment towards supporting the well-being and the sustainable development of each stakeholder and the environment (Cargolux International Airlines, 2007).

The environmental dimension of the Charter stipulates that the signatory firm undertakes to:

- Minimize the impact of its activities on the environment by controlling its usage of water, power and raw materials, by restricting its waste production and by promoting recycling.

- The firm should select its partners, suppliers, and sub-contractors according to ecological criteria, that is, good environmental practices, and/or offer of goods and services that are beneficial to the environment; and

- The firm should encourage its employees to travel to work by means of transport that limit the damage to the environment (public transport, car-pooling, bicycle, coach and so forth) (Cargolux Airlines International, 2009, p.33).

In 2007, Cargolux joined the United National Global Compact. As a signatory to the Compact, firms pledge to embrace, support, and enact a set of values in the areas of human rights, labor standards, anti-corruption, and the environment (Cargolux International Airlines, 2008). In signing up to the UN Global Compact, Cargolux pledged to apply 10 key principles of sound management from both the environmental and social perspectives (Cargolux Airlines International, 2009; 2019). In 2012, Cargolux became a gold contributor to the UN Global Compact Foundation (Cargolux
International Airlines, 2015). Cargolux, together with a number of other companies that are based in Luxembourg, has embraced the 2030 Agenda and the company has pledged its support of the United Nation's 17 Sustainable Development Goals (Cargolux International Airlines, 2018b).

Cargolux is also a member and participant in the International Civil Aviation Organization "Carbon Offsetting and Reduction Scheme for International Aviation" (CORSIA) program (International Civil Aviation Organization, 2020a). Cargolux is also fully compliant with the European Union "Emissions Trading System" (EU-ETS) reporting requirements (Cargolux Airlines International, 2019). In accordance EU-ETS Emissions Trading System, all member airlines are required to produce and submit a mandatory Emissions Monitoring Plan. This plan describes the fuel consumption monitoring and reporting process together with the method applied to calculate the related carbon dioxide $\left(\mathrm{CO}_{2}\right)$ emissions (Cargolux International Airlines, 2012).

Throughout its history, Cargolux has been awarded the "LEAN and GREEN" award, which was established by the Dutch Ministry for Infrastructure and Environment in 2008. This international award recognizes efforts made by a firm to reduce their carbon footprint $\left(\mathrm{CO}_{2}\right.$ emissions) in aviation logistics' by at least 10 percent in a 5-year period (Cargolux International Airlines, 2018b).

Cargolux also continuously assesses the environmental commitment of its appointed ground handling agents throughout its route network (Cargolux International Airlines, 2015).

\section{Cargolux International Airlines carbon footprint}

As an airline who operates wide-body freighter aircraft on long-haul flights, Cargolux's flight operations activity is by far the most demanding in terms of energy consumption and accounts for over $99 \%$ of the carbon dioxide $\left(\mathrm{CO}_{2}\right)$ emitted by the Company (Cargolux International Airlines, 2014). Cargolux's annual Scope 1 carbon dioxide $\left(\mathrm{CO}_{2}\right)$ emissions produced from aircraft operations and the year-on-year change (\%) for the period 2005 to 2018 are presented in Figure 2. As can be seen in Figure 2, the airline's carbon dioxide $\left(\mathrm{CO}_{2}\right)$ emissions increased from 2,845,000 tonnes in 2005 to $4,093,521$ tonnes in 2018, respectively. Figure 2 also shows that the annual carbon dioxide $\left(\mathrm{CO}_{2}\right)$ emissions have predominantly increased on an annual basis due to the growth in the airline's route network and the level of services provided over the review period. There were, however, some significant decreases in the annual carbon dioxide $\left(\mathrm{CO}_{2}\right)$ emissions, 
with the two largest decreases being recorded in 2009 ($13.6 \%)$ and $2012(-8.19 \%)$, respectively (Figure 2). As previously noted, the decrease in 2009 can be attributed to the lower daily utilization of the airline's freighter fleet and the sale of two freighter aircraft to United Parcel Service (UPS) in September 2009 (Cargolux Airlines International, 2010). Small decreases were also recorded in $2006(-1.08 \%), 2008(-0.54 \%)$ and 2018 $(-0.62 \%)$ (Fig. 2), respectively.

Figure 3 presents Cargolux's annual carbon dioxide $\left(\mathrm{CO}_{2}\right)$ emissions per available tonne kilometre (ATK) and the year-on-year change (\%) from 2005 to 2018. An available tonne kilometre (ATK) is a measure of transport output and is calculated as the product of the aircraft payload (as measured in metric tonnes) by the actual number of kilometres flown by the aircraft (Medlik, 2003). It can be observed in Figure 3, that Cargolux's carbon dioxide $\left(\mathrm{CO}_{2}\right)$ emissions per available tonne kilometre (ATK) have decreased from a high of 386.5 grams per ATK to a low of 330.8 grams per ATK in 2018. This is a very favorable trend given the airline's route network expansion and the growth in services throughout the study period. Another important factor has been the operation of the fuel-efficient Boeing 747-8 freighter which has lower aircraft emissions, and thus, helps to mitigate the carbon footprint from aircraft operations. Figure 3 shows that the highest single annual increase in the carbon dioxide $\left(\mathrm{CO}_{2}\right)$ emissions per available tonne kilometre (ATK) occurred in $2011(+3.12 \%)$, whilst the smallest annual decrease in this metric was reported in $2007(-0.51 \%)$ Over the latter years of the study (2012-2018), Cargolux was able to reduce its carbon dioxide $\left(\mathrm{CO}_{2}\right)$ emissions per available tonne kilometre (ATK) in all years, with the only exception occurring in 2017 , when they rose by 2.74\% (Fig. 3).

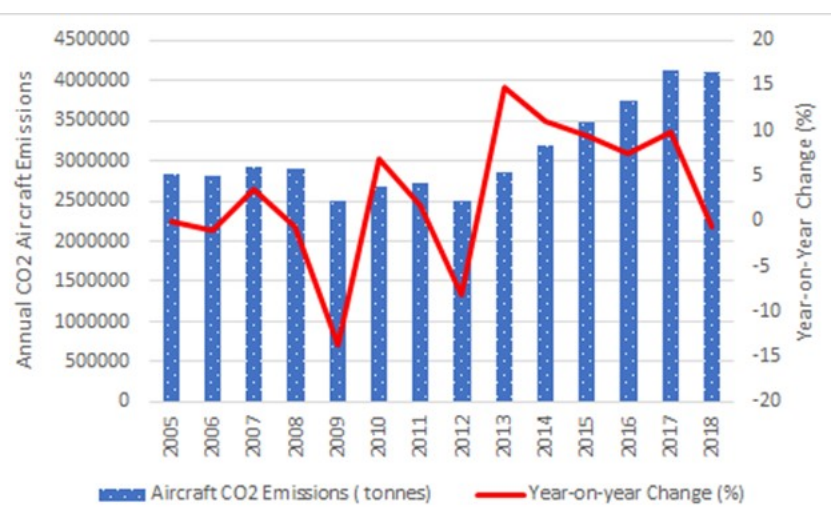

Fig. 2 Cargolux International Airlines annual Scope 1 aircraft emissions and year-on-year change (\%): 2005-2018

Source: Cargolux International Airlines (2009, 2010, 2012, 2015, 2016, 2019)

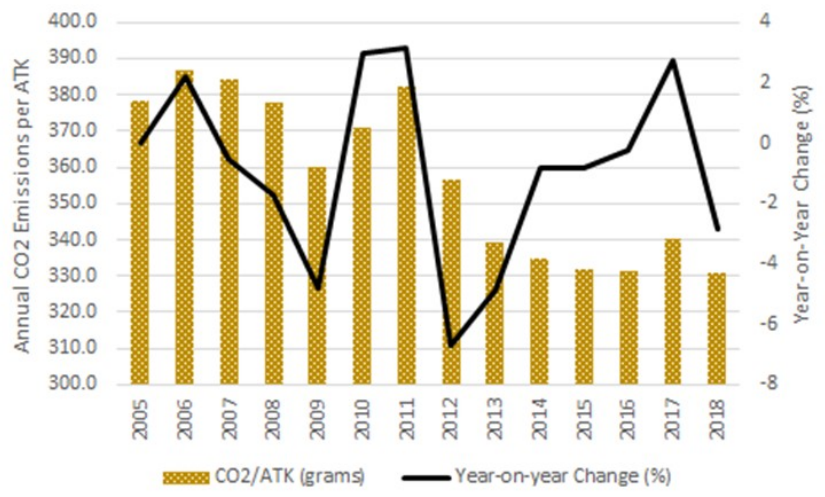

Fig. 3 Cargolux International Airlines annual carbon dioxide $\left(\mathrm{CO}_{2}\right)$ emissions per available tonne kilometre (ATK) and year-on-year change (\%): 2005-2018. Source: Cargolux International Airlines $(2009,2012,2015,2018 b, 2019)$

Figure 4 presents Cargolux's annual carbon dioxide $\left(\mathrm{CO}_{2}\right)$ emissions per available freight tonne kilometre (FTK) and the year-on-year change (\%) from 2005 to 2018. A freight tonne kilometre (FTK) is a measure of the mass of air freight carried multiplied by the distance that the air cargo is carried on a flight (Daley, 2016). As discussed below, Cargolux has implemented a range of carbon footprint reduction measures that have played a key role in reducing the airlines annual carbon footprint per freight tonne kilometre performed (FTK) over the study period. This is demonstrated by the year-on-year percentage change line graph, which is more negative than positive, that is, more values are below the line than above. Figure 4 shows that Cargolux has been able to reduce its carbon dioxide $\left(\mathrm{CO}_{2}\right)$ emissions per freight tonne kilometre (FTK) from a high of 540 grams per FTK in 2011 to a low of 486 grams per FTK in 2017. In 2018, Cargolux achieved its second lowest level of grams of carbon dioxide $\left(\mathrm{CO}_{2}\right)$ per FTK (487 grams). The highest single annual increase in carbon dioxide $\left(\mathrm{CO}_{2}\right)$ emissions per freight tonne kilometre (FTK) occurred in 2011, when they increased by $4.44 \%$ on the 2010 levels. The lowest single annual decrease in carbon dioxide $\left(\mathrm{CO}_{2}\right)$ emissions per freight tonne kilometre (FTK) was recorded in 2014, when they decreased by $-0.19 \%$ on the previous year's levels. Cargolux's annual FTKs grew from 5.1 billion FTKs in 2004 to 8.40 billion FTKs in 2018. Despite this strong growth in air freight traffic Cargolux has successfully been able lower its carbon dioxide $\left(\mathrm{CO}_{2}\right)$ emissions per freight tonne kilometre (FTK), which is a very favorable trend and, once again highlights the very important influence of the operation of the Boeing 747-8 freighter fleet has had on the airline's carbon footprint as well as the other carbon footprint mitigation initiatives discussed below. 


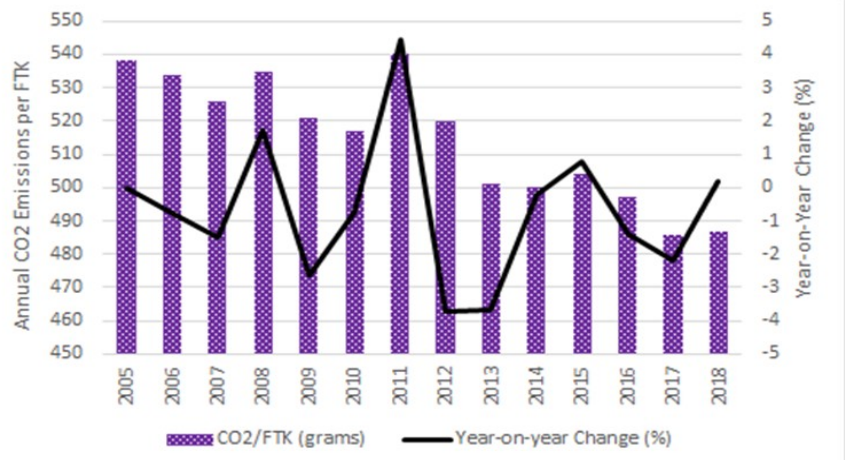

Fig. 4 Cargolux International Airlines annual carbon dioxide $\left(\mathrm{CO}_{2}\right)$ emissions per available freight tonne kilometre (FTK) and year-onyear change (\%): 2005-2018. Source: Cargolux International Airlines (2009, 2012, 2015, 2018b, 2019).

Figure 5 presents Cargolux's annual Scope 1 direct carbon dioxide $\left(\mathrm{CO}_{2}\right)$ emissions arising from the use of its ground service equipment (GSE) and the year-onyear change (\%) from 2012 to 2018 . As can be observed in Figure 5, Cargolux has largely been able to reduce its annual Scope 1 ground services emissions throughout the study period. This is demonstrated by the year-onyear percentage change line graph, which is more negative than positive, that is, there are more values are below the line than above. Figure 5 shows that the airline's annual Scope 1 ground services emissions arising from GSE usage decreased from a high of 289 tonnes in 2015 to a low of 49 tonnes in 2017. The largest single annual increase in the airline's Scope 1 emissions arising from GSE usage was recorded in 2015, when the annual Scope 1 emissions increased by $24.03 \%$ on the previous year's levels. Figure 5 shows that there was a very substantial decrease in the airline's annual Scope 1 emissions arising from GSE usage in 2017 , when these emissions declined by $81.22 \%$ on the 2016 levels. Th reason for this significant decrease is not stipulated in the relevant Cargolux annual sustainability report. However, other airlines, for example, Finnair, have been able to achieve similar significant carbon dioxide $\left(\mathrm{CO}_{2}\right)$ reductions from the use of electrically powered GSE.

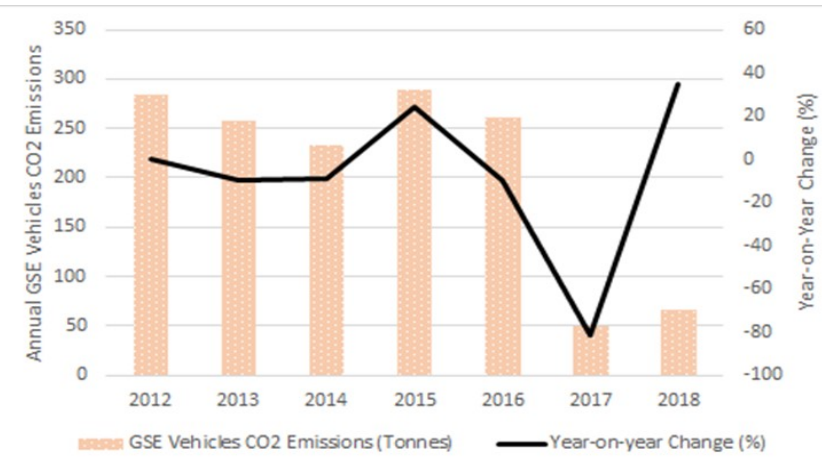

Fig. 5 Cargolux International Airlines annual Scope 1 ground service equipment and vehicles emissions and year-on-year change (\%):
2012-2018. Note: data prior to 2012 not available. Source: Cargolux International Airlines $(2015,2018 b, 2019)$

Figure 6 presents Cargolux's annual Scope 2 indirect facilities carbon dioxide $\left(\mathrm{CO}_{2}\right)$ emissions and the year-on-year change (\%) from 2012 to 2018. The annual Scope 2 accounts for greenhouse emissions from the purchased electricity, steam, heating, and cooling procured by Cargolux (Cargolux International Airlines, 2019). It is important to note that all the electricity that is consumed by Cargolux in Luxembourg is provided from $100 \%$ renewable hydroelectric sources (Cargolux International Airlines, 2014). Luxembourg has cold winters (Eccardt, 2005), and hence, there is a requirement by Cargolux to heat its offices and facilities. As can be observed in Figure 6, Cargolux's annual Scope 2 indirect carbon dioxide emissions $\left(\mathrm{CO}_{2}\right)$ have fluctuated throughout the study period reflecting energy requirements of the company. The highest annual Scope 2 indirect carbon dioxide emissions $\left(\mathrm{CO}_{2}\right)$ occurred in 2014 (2,513 tonnes), whilst the lowest annual Scope 2 indirect carbon dioxide emissions $\left(\mathrm{CO}_{2}\right)$ were recorded in 2017 (2,003 tonnes). The largest single annual increase in the airline's annual Scope 2 indirect carbon dioxide emissions $\left(\mathrm{CO}_{2}\right)$ occurred in 2013 , when these emissions increased by $10.21 \%$ on the 2012 levels. The largest single annual decrease in these emissions was in 2017 (--10.38\%) (Fig. 6).

\section{Cargolux International Airlines carbon footprint mitigation measures}

\section{Aircraft fleet renewal}

The most significant reductions in Cargolux's carbon dioxide $\left(\mathrm{CO}_{2}\right)$ emissions have been achieved through the airline's fleet renewal program. As previously noted, Cargolux was the launch customer for the next generation Boeing 747-8F freighter aircraft. Cargolux

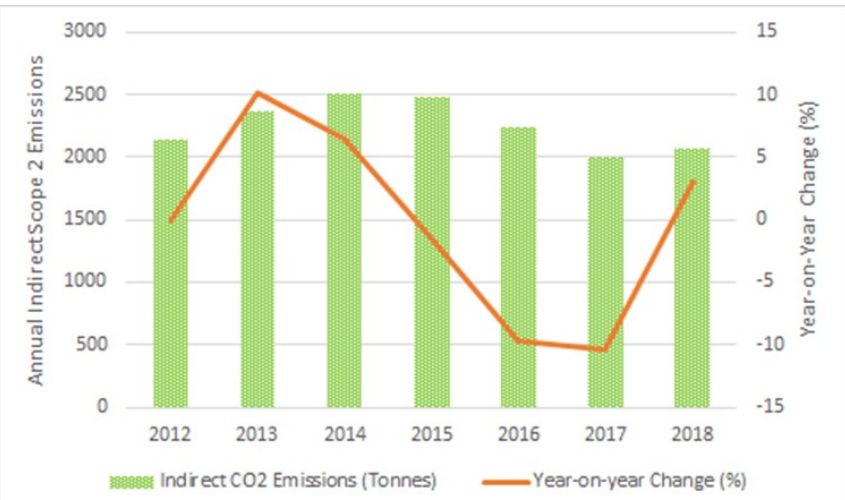

Fig. 6 Cargolux International Airlines annual Scope 2 indirect facilities carbon dioxide $\left(\mathrm{CO}_{2}\right)$ emissions and year-on-year change (\%): 2012-2018. Note: data prior to 2012 not available. Source: Cargolux International Airlines (2015, 2018b, 2019). 
had ordered 13 of these aircraft and held options to purchase two more. Cargolux was the first airline to operate this aircraft type. The 13 aircraft were scheduled to be delivered in 2014 (Cargolux Airlines International, 2009). Because a reduction of carbon dioxide $\left(\mathrm{CO}_{2}\right)$ emissions can most effectively be achieved from a reduction in aircraft fuel consumption, Cargolux commenced a fleet rollover program in 2011 that entailed the introduction of the Boeing 747-8 freighter, which is the most fuel efficient and environmentally friendly aircraft in its class. The new Boeing 747-8 freighter aircraft would gradually replace Cargolux's 747-400 freighter fleet (Cargolux Airlines International, 2015). In 2016, Cargolux concluded its fleet rollover program following the delivery of its 14 th and final Boeing 747-8 freighter aircraft entering its fleet (Cargolux Airlines International, 2017c).

\section{Cargolux - SkyCell Partnership}

Cargolux has partnered with the Swiss company SkyCell to offer Cargolux's pharmaceutical shippers' temperature-controlled container solutions. The "SkyCell" aircraft containers offer a lower tare weight, thereby reducing carbon dioxide $\left(\mathrm{CO}_{2}\right)$ emissions from the lower fuel burn (Cargolux Airlines International, 2018b).

\section{Continuous descent operation (CDO): fuel saving and emissions reduction initiative}

In 2018, Cargolux participated in the inaugural meeting to establish "continuous descent operations (CDO) at Luxembourg Airport Cargolux subsequently cooperated with the local air navigation service provider (ANSP) to develop CDOs arrivals into Luxembourg (Cargolux International Airlines, 2019). A continuous descent operation (CDO) is one in which the arriving aircraft descends from its cruise level to an airport with its engines at near-idle thrust (Itoh \& Uejima, 2013). With the Cargolux CDO program a number of waypoints on the flight route were established that enable pilots to efficiently plan the descent of their aircraft. Both CDOs and CDAs (Continuous Descent Operations and Approach) methodologies offer the potential for significant fuel savings as well as substantial reduction in carbon dioxide $\left(\mathrm{CO}_{2}\right)$ emissions. For example, a $\mathrm{CDO}(\mathrm{F})$ arrival can provide fuel savings of approximately $250 \mathrm{~kg}$ per flight for a Boeing B747 freighter aircraft, as the engines remain at a near-idle thrust during the process (Cargolux Airlines International, 2019).

\section{Engine compressor washing}

In 2007 and 2008, research undertaken by Cargolux's Engineering Department found that certain aircraft engine types consume less fuel if the engine core is regularly washed and cleaned. This cleaning removes the deposits that have accumulated over time on the compressor blade airfoils. The washing of the engine core also improves air flow and overall engine performance. Cargolux have noted that washed General Electric engines consume $0.18 \%$ less fuel. The same procedure applied to Rolls Royce engines did not provide substantial fuel savings. In 2008, Cargolux began to regularly clean both General Electric and Rolls Royce engines. Based on the company's aircraft fuel consumption and the General Electric fleet composition, annual savings of around 500 tonnes of fuel per year were achieved. This fuel reduction also translates into lower carbon dioxide $\left(\mathrm{CO}_{2}\right)$ emissions (Cargolux Airlines International, 2009, p. 31).

The "Core Engine Compressor" wash was perfected by Cargolux in 2018. This cleaning process is performed on the airline's GENX-2B, CF6-80C2B5F, and selected RB211-524H2-T engines (Cargolux International Airlines, 2019). Like earlier initiatives, this practice is a further fuel-saving measure that also helps mitigate aircraft emissions.

\section{Environmentally friendly beam solution}

In 2017, Cargolux Airlines ratified an agreement with Trinkaus-Solutions (Germany) for the use of the company's "squAIR" -timber product. With a tare weight of only 1.2 kilograms per metre, the beam is $80 \%$ lighter than conventional wood, and thus, lowers fuel consumption and carbon dioxide $\left(\mathrm{CO}_{2}\right)$ emissions for Cargolux aircraft. Cargolux has estimated that its use of the "squAIR"-timber product potentially reduces its fuel consumption by approximately 1,200 tonnes per year (Cargolux Airlines International, 2018b)

\section{Fuel consumption reduction initiative}

Cargolux has established a "Fuel Efficiency Round Table" initiative. In 2016, Cargolux's fuel-saving initiative saved 2,031 tons of fuel from its flight operations, which also resulted in a reduction of 6,398 tons of carbon dioxide $\left(\mathrm{CO}_{2}\right)$ emissions (Cargolux Airlines International, 2017b).

\section{Future Air Navigation System (FANS) Operations}

In 2010, Cargolux completed a program to equip all aircraft in its own aircraft fleet with the Iridium onboard 
satellite communications system. The Iridium system offers global coverage, including over the polar regions. Hence, in June 2010, Cargolux aircraft were able to operate on "Future Air Navigation System" (FANS) routes and thereby achieve significant savings in flying time (Cargolux International Airlines, 2011). The "Future Air Navigation System" (FANS) is an operational concept which relies upon satellite-based navigation and communication to provide the improvements required in communication, navigation, and surveillance (CNS) to efficiently handle the projected increase in traffic levels (Golmohammad \& Mehdizadeh Dastjerdi, 2012).

At the time of the introduction of this new service, the most important FANS route throughout the Cargolux network was located over the Gobi Desert between Almaty and Hong Kong. In 2010, this route was served on four to six flights per week. The fuel savings were very significant as flight time is reduced by 30 to 35 minutes on each flight. The fuel savings that could be achieved are estimated at 700 tonnes per year, or over 2,200 tonnes of carbon dioxide $\left(\mathrm{CO}_{2}\right)$ emissions. Cargolux aims to extend FANS flights throughout its worldwide network, wherever air routes can support this system and offer a shorter alternative routing (Cargolux International Airlines, 2011).

\section{Performance improvement package (PIP)}

Cargolux has implemented a retrofit program for the airline's GEnx engines from the early Boeing 747-8Fs that had entered the airline's fleet. This initiative improves both the efficiency and life of the engine, but also has a positive impact on fuel consumption (Cargolux Airlines International, 2018b), and hence, on carbon dioxide $\left(\mathrm{CO}_{2}\right)$ emissions.

\section{Reduction in aircraft weight}

In 2008, a weight reduction program was undertaken for the entire Cargolux aircraft fleet. Around $250 \mathrm{~kg}$ of material was removed from each aircraft through a modification of the aircraft's bulk hold compartment, the removal of unused cargo locks, and through a modification of the airline's "fly-away maintenance kit". These initiatives resulted in a reduction of 2,100 tonnes of carbon dioxide $\left(\mathrm{CO}_{2}\right)$ per annum (Cargolux International Airlines, 2009).

\section{The use of fixed electrical ground power systems}

The auxiliary power unit (APU) is a small gas size turbine engine or small powerplant located near the belly of an aircraft (Anvekar, 2016). APU's are units that supply the essential requirements of the aircraft whilst it is on the ground at the airport and without the main engines operating, or when no external power source is available (Smith, 2004). These essential services include electricity, compressed air, and airconditioning (Filippone, 2012). In 2007, Cargolux launched a network wide campaign to ensure that, wherever possible, electric ground power was obtained from the airport, from either a diesel-powered ground power unit (GPU), or from a fixed electrical ground power unit (FEGP). Ground power is far more fuel efficient (Cargolux International Airlines, 2009) and produces less harmful emissions. Consequently, a ground power unit is used to supply electricity to the aircraft wherever possible (Cargolux International Airlines, 2018b).

\section{The use of sustainable aviation fuels}

Cargolux was one of the founding members of the "Sustainable Aviation Fuel Users Group" (SAFUG). This body is a cross industry initiative whose objective is to promote and bring to market sustainable aviation biofuels (Cargolux International Airlines, 2019). The Sustainable Aviation Fuel User's Group (SAFUG) brings together airlines and other stakeholders all of whom have a common interest in developing a longterm, renewable source of aviation fuel. An important objective of this group is that proposed aviation biofuels does not compete with agricultural food production, does not pose a threat to fragile eco-systems, and also provides a positive socio-economic impact (Cargolux International Airlines, 2011).

\section{Three engine taxing to aircraft parking position}

Cargolux has implemented a procedure whereby aircraft shut down one of four engines during the taxi to the parking position on the ramp (Cargolux International Airlines, 2018b). This results in fuel savings, whilst also reducing carbon dioxide $\left(\mathrm{CO}_{2}\right)$ emissions.

\section{Cargolux International Airlines road feeder services}

In the global air cargo industry, airlines utilize trucking services, which are often referred to as road feeder services (RFS), to extend their route networks and traffic catchment areas (Beifert, 2016; Merkert \& Alexander, 2018; Morrell \& Kleing, 2019). Historically, Cargolux has operated a very extensive European road feeder service linking Luxembourg with key peripheral cities located throughout the continent. These road feeder services are provided by external trucking firms. To optimize the efficiency of these services, whilst also mitigating carbon dioxide (CO2) emissions, in 2016, Cargolux developed a "Trucking Management System" (TMS). This system was fully implemented in 2017. In 2018, 93.7\% of the trucks used by Cargolux were in accordance with the European Union's Euro 6 
emissions, $2.7 \%$ were in accordance with the Euro 5 standards, and the remaining 3.5\% were in accordance with the EURO 4 standards (Cargolux Airlines International, 2019).

\section{CONCLUSIONS}

In conclusion, this study has investigated the strategies and measures that can be defined and implemented by a dedicated all-cargo airline to mitigate the environment impact of carbon dioxide $\left(\mathrm{CO}_{2}\right)$ emissions from their flight and ground operations. To achieve the objectives of the study, Cargolux International Airlines was selected as the case airline. The research undertaken in this study used an in-depth qualitative longitudinal case study research approach. All the data gathered for the study was examined using document analysis. The study covered the period 2005 to 2018.

The case study revealed that Cargolux's annual carbon dioxide $\left(\mathrm{CO}_{2}\right)$ emissions from its flight operations, which are the company's largest source of such emissions, increased from a low of 2,845,000 tonnes in 2005 to a high of 4,119, 139 tonnes in 2017. In 2018, the final year of the study, Cargolux's annual carbon dioxide $\left(\mathrm{CO}_{2}\right)$ emissions totaled 4,093,521 tonnes, which was the second highest annual total during the study period. The increase in carbon dioxide $\left(\mathrm{CO}_{2}\right)$ emissions are due to the expansion of services, growth in the airline's freighter aircraft fleet, and route network expansion. Throughout the study period, Cargolux's annual carbon dioxide $\left(\mathrm{CO}_{2}\right)$ emissions per available tonne kilometre (ATK) largely displayed a downward trend, decreasing from a high of 386.5 grams per ATK in 2006 to a low of 330.8 grams per ATK in 2018. A similar trend was observed in Cargolux's annual carbon dioxide $\left(\mathrm{CO}_{2}\right)$ emissions per freight tonne kilometre (FTK) which decreased from a high of 540 grams per FTK in 2011 to a low of 486 grams per FTK in 2017. The acquisition and operation of a fleet of the next generation, fuel efficient Boeing B747-8 freighter aircraft has positively influenced the airline's annual carbon dioxide $\left(\mathrm{CO}_{2}\right)$ emissions per ATK and per FTK. The reduction in these metrics is a very favourable achievement given the route network expansion, and higher flight frequencies and reflects the airline's commitment to environmentally sustainable operations. In addition, the wide range of carbon footprint mitigation measures has also had a very positive influence on the airline's annual carbon dioxide $\left(\mathrm{CO}_{2}\right)$ emissions per ATK and per FTK.

Cargolux's annual carbon dioxide $\left(\mathrm{CO}_{2}\right)$ emissions arising from the use of ground service equipment (GSE) displayed a downward trend over the period 2012 to 2018, with only one increase in such emissions being recorded in 2018, when emissions increased by $34.69 \%$ on the 2017 levels. The highest annual level of carbon dioxide $\left(\mathrm{CO}_{2}\right)$ emissions arising from the use of ground service equipment (GSE) was recorded in 2015 (289 tonnes), whilst the lowest annual level was in 2017 (49 tonnes). The overall downward trend suggests that the airline has been able to successfully mitigate its annual carbon dioxide $\left(\mathrm{CO}_{2}\right)$ emissions arising from the use of ground service equipment (GSE), and hence, mitigate its carbon footprint.

The case study revealed that Cargolux throughout the study period has implemented a very wide range of initiative and strategies to mitigate the impact of carbon dioxide $\left(\mathrm{CO}_{2}\right)$ emissions from both its flight and ground operations. The most substantial reduction in carbon dioxide $(\mathrm{CO} 2)$ emissions have been achieved through the airline's fleet rollover programme in which Cargolux acquired a fleet of Boeing 747-8 freighter aircraft. The fleet rollover programme commenced in 2011 and was concluded in 2016, when Cargolux took delivery of its fourteenth Boeing 747-8 freighter aircraft. As previously noted, these aircraft are the most fuel efficient and environmentally friend aircraft in their class. Cargolux has also defined and implemented a number of key initiatives that have focused on fuel efficiency and the associated reduction in carbon dioxide $\left(\mathrm{CO}_{2}\right)$ emissions. These initiatives include the continuous descent operations (COD), engine compressing washing, the establishment of a Fuel Efficiency Round Table, the use of the Future Air Navigation System (FANS) operations, performance improvement package, reduction in aircraft weight, and the use of three engine taxiing to the ramp parking position at Luxembourg's Findel Airport.

The use of ground power systems alleviates the necessity for Cargolux's aircraft to use their auxiliary power unit (APU) to provide power during the time the aircraft are being serviced on the ground. This practice alleviates the use of fuel to power the aircraft's APU, and thus, reduces carbon dioxide $\left(\mathrm{CO}_{2}\right)$ emissions during the aircraft turnaround process.

Cargolux has also been able to mitigate its carbon dioxide (CO2) emissions through the use of the lightweight "squAIR" timber product and through the use of lighter weight SkyCell aircraft containers that are used by the company's pharmaceutical shippers'.

Finally, Cargolux has recognized the environmentally favorable benefits of sustainable aviation biofuels and, as such, is a member of the Sustainable Aviation Fuel Users Group".

\section{REFERENCES}

Abdullah, M.A., Chew, B.C. \& Hamid, S.R. (2016) Benchmarking key success factors for the future green airline industry. Procedia 
- Social and Behavioral Sciences 224, 246 - 253. doi: https://doi.org/10.1016/j.sbspro.2016.05.456

Air Transport World. (1998) Cargo development award: Cargolux. Air Transport World 35(2), 42-43.

Andrew, D.P.S., Pedersen, P.M. \& McEvoy, CD. (2011) Research Methods and Design in Sport Management. Human Kinetics, Champaign.

Anvekar, M.R. (2016) Aircraft Propulsion. PHI Learning Private Ltd, New Delhi.

Attanasio, G. (2018) Naples International Airport and airport carbon accreditation (ACA). In: WIT Transactions on Ecology and the Environment: Air Pollution XXVI (ed. by J. Casares, J. Longhurst, G. Passerini, G. Perillo \& J. Barnes), 465-474. WIT Press, Southampton.

Bardell, N.S. \& Ashton, M.J. (2018) Some issues affecting potential stakeholder uptake of sustainable aviation fuel within Australia: A case study conducted at Darwin International Airport. Australian Journal of Mechanical Engineering, 1-13. doi: https://doi.org/10.1080/14484846.2018.1478700

Bauen, A. \& Nattrass, L. (2018) Sustainable aviation biofuels: Scenarios for deployment. In: Biokerosene: Status and Prospects (ed. by M. Kaltschmitt \& U. Neuling), 703-721. Springer-Verlag, Berlin.

Baxter, G. (2019) A strategic analysis of Cargolux Airlines International position in the global air cargo supply chain using Porter's Five Forces Model. Infrastructures 4(1), 6. doi: https://doi.org/10.3390/infrastructures4010006

Baxter, G.S. \& Bardell, N.S. (2017) Can the renewed interest in ultra-long-range passenger flights be satisfied by the current generation of civil aircraft? Aviation 21(2), 42-54. doi: https://doi.org/10.3846/16487788.2017.1336485

Baxter, G., Srisaeng, P. \& Wild, G. (2020) The use of aviation biofuels as an airport environmental sustainability measure: The case of Oslo Gardermoen Airport. Magazine of Aviation Development 8(1), 6-17. doi. https://doi.org/10.14311/MAD.2020.01.01

Beifert, A. (2016) Role of air cargo and road feeder services for regional airports - Case studies from the Baltic Sea Region. Transport and Telecommunication 17(2), 87-99. doi. https://doi.org/10.1515/ttj-2016-0008

Belson, J. (1977) Cargolux Airlines International. Flight International 112(3568), 311-312.

Boeing Commercial Airplanes. (2011), Boeing delivers first 747-8 freighter to Cargolux. News Release 12 October. Retrieved from: http://boeing.mediaroom.com/2011-10-12-boeing-delivers-first747-8-freighter-to-cargolux.

Boeing Commercial Airplanes. (2018) World air cargo forecast 2018-2037.

Retrieved from: https://www.boeing.com/resources/boeingdotcom/commercial/ab out-our-market/cargo-market-detail-wacf/downloadreport/assests/pdfs/2018 WACF.pdf.

Budd, T. (2017) Environmental impacts and mitigation. In: Air Transport Management: An International Perspective (ed. by L. Budd \& S. Ison), 283-306. Routledge, Abingdon, 283-306.

Buyck, C. (2004) Built for cargo. Air Transport World 41(13), 26 28.

Cargolux International Airlines. (2007) Annual Report 2006. Cargolux International Airlines, Luxembourg.

Cargolux Airlines International. (2008) Annual Report 2007. Retrieved from: http://paperjam.lu/sites/default/files/oldfiles/fichiers contenus/rapports_annuels/2007/Cargolux_2007_G B.pdf.

Cargolux Airlines International. (2009) Annual Report 2008 Available online: http://paperjam.lu/sites/default/files/oldfiles/fichiers_contenus/rapports_annuels/2008/Cargolux_2008_G B.pdf (accessed on 06 January 2019).
Cargolux International Airlines. (2010) Annual Report 2009. Cargolux International Airlines, Luxembourg.

Cargolux International Airlines. (2011) Annual Report 2010 Cargolux International Airlines, Luxembourg.

Cargolux International Airlines. (2012) Annual Report 2011. Cargolux International Airlines, Luxembourg.

Cargolux International Airlines. (2014) Sustainability Report 2013. Cargolux International Airlines, Luxembourg.

Cargolux International Airlines. (2015) Sustainability Report 2014. Cargolux International Airlines, Luxembourg.

Cargolux International Airlines. (2016) Annual Report 2015. Cargolux International Airlines, Luxembourg.

Cargolux International Airlines. (2017a) Environmental excellence. Retrieved from:https://www.cargolux.com/medialibrary/files/Sustainability-Flyer-2017.pdf.

Cargolux International Airlines. (2017b) Annual Report 2016. Cargolux International Airlines, Luxembourg.

Cargolux International Airlines. (2017c) Sustainability Report 2016 Retrieved from: https://www.cargolux.com/medialibrary/files/CSR/CSR-Report-2016.pdf..

Cargolux International Airlines. (2018a). Certificate. Retrieved from:https:/www.cargolux.com/media-library/files/CargoluxCertificate-ISO-14001-2019-2021.pdf.

Cargolux International Airlines. (2018b) Sustainability Report 2017. Retrieved from: https://www.csr.cargolux.com/wpcontent/uploads/2018/04/Cargolux_Sustainability $\neg$ report $\neg 2017$.p df. Accessed 07/05/2020.

Cargolux International Airlines. (2019) Sustainability Report 2018. Retrieved from https://www.cargolux.com/medialibrary/files/csr/csr-report-20182.

Cargolux International Airlines. (2020a) Environmental policy Retrieved from:https://www.cargolux.com/medialibrary/files/environmental-policy.pdf.

Cargolux International Airlines. (2020b) Introducing Cargolux. Retrieved from: https://www.cargolux.com/aboutus/profile/introducing-cargolux.

Cargolux International Airlines. (2020c) Key figures. Retrieved from: https://www.cargolux.com/about-us/profile/key-figures.

Cargolux Italia. (2020) Introducing Cargolux. Retrieved from: https://www.cargolux-italia.com/About-us/profile/introducingcargolux.

Chen, F.Y. (2012) Managers' views on environmental management: An examination of the Taiwanese airline industry. Journal of Sustainable Development 6(1), 65-75.

Conway, P. (2012) Volume switch. Flight International 181(5344), 28-29.

Cook, G.N. \& Billig, B. (2017) Airline Operations and Management: A Management Textbook. Routledge, Abingdon.

Daley, B. (2016) Air Transport and the Environment. Routledge, Abingdon.

Derrington, M. L. (2019) Qualitative Longitudinal Methods: Researching Implementation and Change. SAGE Publications, Thousand Oaks.

Dodd, T., Orlitzky, M. \& Nelson, T. (2018) What stalls a renewable energy industry? Industry outlook of the aviation biofuels industry in Australia, Germany, and the USA. Energ. Policy 123, 92-103. doi: https://doi.org/10.1016/j.enpol.2018.08.048

Dresner, M. \& Zou, L. (2017) Air cargo and logistics. In: Air Transport Management: An International Perspective (ed. by L. Budd \& S. Ison), 247-264. Routledge, Abingdon.

Drewer, J., Howard, D. \& McNamara, N. (2018) Greenhouse gas (GHG) and biogenic volatile organic compound (BVOC) fluxes associated with land-use change to bio-energy crops. In: Greenhouse Gas Balances of Bioenergy Systems (ed. by P. Thornley \& P. Adams), 77-96. Academic Press, London. 
Eccardt, T.M. (2005) Secrets of the Seven Smallest States of Europe: Andorra, Liechtenstein, Malta, Monaco, San Marino and Vatican City. Hippocrene Books, New York.

Filippone, A. (2012) Advanced Aircraft Flight Performance. Cambridge University Press, Cambridge.

Flight International. (1979) World airline directory. Flight International 115(3658), 1356.

Gegg, P., Budd, L. \& Ison, S. (2014) The market development of aviation biofuel: Drivers and constraints. J. Air Transp. Manag. 39, 34-40. doi: https://doi.org/10.1016/j.jairtraman.2014.03.003

Girella, L. (2018) The Boundaries in Financial and Non-Financial Reporting: A Comparative Analysis of Their Constitutive Role. Routledge, Abingdon.

Golmohammad, F. \& Mehdizadeh Dastjerdi, A. (2012) The economic analysis of satellite-based CNS/ATM in Iranian air transportation. In: Air Transport and Operations: Proceedings of the Third International Air Transport and Operations Symposium 2012 (ed. by R. Curran, L. Fischer, D. Pérez, K. Klein, J. Hoekstra, P. Roling. \& W.J.C. Verhagen), 540-551. IOS Press $\mathrm{BV}$, Amsterdam.

Graver, B., Zhang, K. \& Rutherford, D. (2019) $\mathrm{CO}_{2}$ emissions from commercial aviation, 2018. Retrieved from: https://theicct.org/publications/co2-emissions-commercialaviation-2018.

Green, W. \& Swanborough, G. (1975) The Observer's World Airlines and Airliners Directory. Frederick Warne \& Co. Ltd, London.

Greenhouse Gas Protocol. (2020) About us. Retrieved from: https://ghgprotocol.org/about-us.

Hagmann, C., Semeijn, J. \& Vellenga, D.B. (2015) Exploring the green image of airlines: Passenger perceptions and airline choice. J. Air Transp. Manag. 43, 37-45. doi: https://doi.org/10.1016/j.jairtraman.2015.01.003

Harrison, R.M., Masiol, M. \& Vardoulakis, S. (2015) Civil aviation, air pollution and human health. Environmental Research Letters 10,041001

Hassett, M.E. \& Paavilainen-Mäntymäki, E. (2013) Longitudinal research in organizations: An introduction, In: Handbook of Longitudinal Research Methods in Organisation and Business Studies (M.E. Hassett \& E. Paavilainen-Mäntymäki), 1-22. Edward Elgar Publishing, Cheltenham.

Hazel, R.A., Blais, J.D., Browne, T.J. \& Benzon, D.M. (2011) Resource Guide to Airport Performance Indicators. Airport Cooperative Research Program Report 19. Transportation Research Board, Washington.

International Air Transport Association. (2013) Passenger demand grew as air cargo declined in 2012, Press Release 02. Retrieved from: https://www.iata.org/en/pressroom/pr/2013-01-31-01/.

International Air Transport Association. (2018) Climate change \& CORSIA. Retrieved from: https://www.iata.org/contentassets/c4f9f0450212472b96dac114a0 $6 \mathrm{cc} 4 \mathrm{fa} /$ fact-sheet-climate-change.pdf.

International Air Transport Association. (2020) Air cargo matters. Retrieved

from: https:/www.iata.org/en/programs/cargo/sustainability/benefits/.

International Civil Aviation Organization. (2011) Airport Air Quality Manual. Document No 9889. ICAO, Montreal.

$\begin{array}{cccc}\text { International Civil } & \text { Aviation } & \text { Organization. } & \text { (2020a) } \\ \text { CORSIA/Airplane } & \text { operator. } & \text { Retrieved } & \text { from: }\end{array}$ https://www.icao.int/environmental-

protection/CORSIA/Lists/CORSIAAeroplaneOperator/DispForm. aspx?ID=1993\&Source=https $\% 3 \mathrm{~A} \% 2 \mathrm{~F} \% 2 \mathrm{Fwww} \% 2 \mathrm{Eicao} \% 2 \mathrm{Eint}$ $\% 2$ Fenvironmental $\% 2$ Dprotection $\% 2$ FCORSIA $\% 2$ FLists $\% 2 \mathrm{FCO}$ RSIAAeroplaneOperator\%2FAllItems\%2Easpx\%3FPaged\%3DT RUE\%26p\%5FID\%3D517\%26PageFirstRow\%3D871\%26\%26Vi ew\%3D\%257BE5343EE9\%2D3D4C\%2D403B\%2DBF4F\%2D55
0DBA175599\%257D\%23InplviewHashe5343ee9\%2D3d4c\%2D4 03b\%2Dbf4f\%2D550dba175599\%3D\&ContentTypeId=0x0100A BCCFCC5A21C174B88BEBD4162FB312B

International Civil Aviation Organization. (2020b) 4. What are the mechanisms for the CORSIA implementation? How will ICAO support States to implement the CORSIA? Retrieved from: https://www.icao.int/environmentalprotection/Pages/A39_CORSIA_FAQ4.aspx..

Itoh, E. \& Uejima, $\bar{K}$. (2013) Applying flight-deck interval management based continuous descent operation for arrival air traffic to Tokyo International Airport. In: Proceedings of Tenth USA/Europe Air Traffic Management Research and Development Seminar (ATM2013), June 10-13, 2013, Chicago, 1-10.

Javed, T., Ahmed, A., Raman, V., Alqualty, A.B.S. \& Johansson, B. (2019) Combustion-based transportation in a carbon constrained world - A review. In: Pollutants from Energy Sources: Characterization and Control (ed. by R.A. Agarwal, A.K. Agarwal, T. Gupta \& N. Sharma), 7-34. Springer Nature Singapore, Singapore.

Jones, M. (2009) Sustainable Event Management: A Practical Guide. 2nd ed. Routledge, Abingdon.

Kalaian, S.A. \& Kasim, R.M. (2008) Longitudinal studies. In: Encyclopaedia of Survey Research Methods (ed. by P.J. Lavrakas), 439-440. SAGE Publications, Thousand Oaks.

Maertens, S., Grimme, W., Scheelhaase, J. \& Jung, M. (2019) Options to continue the EU ETS for aviation in a CORSIA-world. Sustainability $11(20), \quad 5703 . \quad$ doi: https://doi.org/10.3390/su11205703

Mazhar, M.U., Bull, R., Lemon, M. \& Bin Saleem Ahmad, S. (2019) Carbon management planning in UK Universities: A journey to low carbon built environment. In: University Initiatives in Climate Change Mitigation and Adaptation (ed. by W. Leal Filho \& R. Leal-Arcas), 33-56. Springer International Publishing, Cham.

Medlik, S. (2003) Dictionary of Travel, Tourism and Hospitality. 3rd ed. Routledge, Abingdon.

Merkert, R. \& Alexander, D. (2018) The air cargo industry. In: The Routledge Companion to Air Transport Management (ed. by N. Halpern \& A. Graham), 29-47. Routledge, Abingdon.

Migdadi, Y.K.A.A. (2020) Green operational strategy for airlines: Content and regional analysis, In: Cases on Green Energy and Sustainable Development (ed. by P. Yang), 193-229. IGI Global, Hershey.

Morrell, P.S. \& Kleing, T. (2019) Moving Boxes by Air: The Economics of International Air Cargo. 2nd ed. Routledge, Abingdon.

Neale, B. (2019) What is Qualitative Longitudinal Research? Bloomsbury Academic, London.

Nelms, D.W. (1996) Small base, big carrier. Air Transport World 33(2), 88-90.

Ngo, C. \& Natowitz, J. (2016) Our Energy Future: Resources, Alternatives and the Environment. John Wiley \& Sons, Hoboken.

Niu, S.Y., Liu, C.L., Chang, C.C. \& Ye, K.D., (2016) What are passenger perspectives regarding airlines' environmental protection? An empirical investigation in Taiwan. J. Air Transp. Manag. 55, 84-91. doi: https://doi.org/10.1016/j.jairtraman.2016.04.012

O'Leary, Z. (2004) The Essential Guide to Doing Research. SAGE Publications, London.

Ostrower, J. (2011) 747-8 freighter on the 'home stretch'. Flight International 180(5303), 9.

Roza, G. (2009) Reducing Your Carbon Footprint on Vacation. The Rosen Publishing Group, New York.

Sales, M. (2013) Air Cargo Management: Air Freight and the Global Supply Chain. Routledge, Abingdon.

Sales, M. (2016) Aviation Logistics: The Dynamic Partnership of Air Freight and Supply Chain. Kogan Pace, London. 
Schäfer, A.W. (2016) The prospects for biofuels in aviation, In: Biofuels for Aviation: Feedstocks, Technology and Implementation (ed. by C.J. Chuck), 3-16. Academic Press, London.

Scott, B.J. \& Trimarchi, A. (2020) Fundamentals of International Aviation Law and Policy. Routledge, Abingdon.

Scott, J. (2014) A Dictionary of Sociology. 4th ed. Oxford University Press, Oxford.

Sgouridis, S., Bonnefoy, P.A. \& Hansman, R.J. (2011) Air transportation in a carbon constrained world: Long-term dynamics of policies and strategies for mitigating the carbon footprint of commercial aviation. Transport. Res. A-Pol. 45(10), 1077-1091. doi: https://doi.org/10.1016/j.tra.2010.03.019

Smith, M.J.T. (2004) Aircraft Noise. Cambridge University Press, Cambridge.

Su, Y., Zhang, P. \& Su, Y. (2015) An overview of biofuels policies and industrialization in the major biofuel producing countries Renew. Sust. Energ. Rev. 50, 991-1003. doi: https://doi.org/10.1016/j.rser.2015.04.032

Teoh, L.E. \& Koo, H.L. (2016) Green air transport system: An overview of issues, strategies and challenges. KSCE J. Civ. Eng. 20(3), 1040-1052. doi: https://doi.org/10.1007/s12205-016-1670$\underline{3}$
Tretheway, M.W. \& Andriulaitis, R.J. (2016) Airport competition for freight. In: Airport Competition: The European Experience (ed. by P. Forsyth, D. Gillen, J. Müller \& H.M Niemeier), 137150. Routledge, Abingdon.

Vásquez, L., Iriarte, A., Almeida, M. \& Villalobos, P. (2015) Evaluation of greenhouse gas emissions and proposals for their reduction at a university campus in Chile. J. Clean. Prod. 108 (Part A), 924-930. doi: https://doi.org/10.1016/j.jclepro.2015.06.073

Wensveen, J.G. (2016) Air Transportation A Management Perspective. 8th ed. Routledge, Abingdon.

Wiedemann, T. \& Minx, J. (2007), A definition of carbon footprint. In: Ecological Economics Research Trends (ed. by C.C. Pertsova), 1-11. Nova Science Publishers, New York.

Yin, R.K. (2018) Case Study Research: Design and Methods. 6th ed. SAGE Publications, Thousand Oaks.

Zhou, T. \& Zhang, J. (2020) Behavioural research on transport and energy in the context of aviation, In: Transport and Energy Research: A Behavioral Perspective (ed. by J. Zhang), 279-294. Elsevier, Amsterdam. 